\title{
Trilogy of Accountability in the Context of Political Party Organizations
}

\author{
Masiyah Kholmi \\ University of Muhammadiyah Malang \\ masiyah@umm.ac.id
}

\begin{abstract}
This study aims to find the trilogy of accountability in the context of political party organizations. This study used qualitative approach with interpretive paradigm and phenomenology method. By using interview and documentation, this study analyzed data with reduction, presentation, verification, and interpretation. The study found evidence that informants have an understanding of the environment values in the existence themselves, political party organization, and social life. The metaphor of trust is applied on the accountability trilogy: accountability of the dimensions of human and God's relationships, accountability of human and human dimensions, and accountability of human and natural dimensions.
\end{abstract}

Keywords: Accountability, Political Party, Trilogy.

\section{INTRODUCTION}

The development of organizations in the reformation era has led to demands for the implementation of organizational accountability. Mistrust of the organization is the fundamental reason of the demand for corporate accountability[1]. The accountability is a requirement to create a good, democratic, and trustworthy governance [2]. Accountability demands as a logical consequence of the relationship between principal and agent. The relationship is called agency relationship [3].

The principal as the party should be held accountable and the agent as the party performs the responsibility and justifies all activities that are the principal's responsibility [4]. The concept of principal-agent in building a corporate accountability framework to the public is in its appreciation of the environment [5].

Accountability is like a "chameleon" which is subjectively constructed and changed according to the context [6]. [7] Accountability is a behavioral aspect of human life that encompasses internal and external behaviors. In terms of internal behavior is spiritual accountability, and external behavior is accountable to the environment, is called external accountability. Two concepts of accountability in sharia accounting construct. First, vertical accountability, the accountability used by management to God. Second, horizontal accountability, accountability used by management to stakeholders and nature [8].

Trilogy of accountability, namely the giver of trust (Allah), the recipient of the mandate (human), and amanah itself (nature). In this trilogy, God rests on the corner of the top triangle, whereas man and nature are each in their basic corners and both are subservient and obedient to Him [9].

With phenomenology method, to understand accountability practice in the context of second level regional election in political party organization, we found three forms of accountability: accountability of candidate quality, legal accountability, and accountability of campaign fund [10]. And accountability practice in the context of post-election of second level head of region at political party organization, found 3 form of accountability: moral accountability, political accountability, and financial accountability [11].

Based on the above explanation, this study examined the understanding of political party leaders in the accountability trilogy in the context of party organization. The purpose of this study was to find an understanding of political party leaders on the accountability trilogy in the context of political party organization.

\section{METHODS}

This study used qualitative approach. This approach aims to understand the phenomenon of what is experienced by the subject of research, a behavior such as perception, motivation, and action holistically and by way of description in the form of words and language in a natural context [12].

This study tries to understand the meaning, then the corresponding paradigm is the interpretive paradigm. The interpretive paradigm has provided a deeper understanding of "accountability" from the informants' point of view in their life as a research subjects. The informants of this study are eight people who are actively involved in daily activities in the organization of political parties.

The instrument of this research is the researcher himself. Therefore, the researcher is the key instrument. Data collection were interview and documentation data. The strategies undertaken in the field are as follows: The results of extracting data from the field were immediately recorded in the manuscript form as field notes. Document data obtained were used to complement and analyze data including data reduction, data presentation, verification, and data interpretation. 


\section{RESULT}

\section{The Accountability Trilogy}

The views of research subjects on accountability are two understandings, namely (1) an understanding of the values of a trustful environment visible on the existence of self, organization, and social life; (2) the meaning of a trusted word that must be carried out as observed through the Articles of Association and the Household Party.

The expression of the Party Advisory Panel (MPP) is as follows: the organization of political parties has a moral force, so humans are accountable to God. Therefore, say true if true and say wrong if wrong. A party organization is not only victory-oriented to in the political office during the election. The implication of victory is not only an indicator of performance, but also in leadership (cadres or party proposals) over the next five years as corruption-free and nepotism.

The concept of a mandate as a metaphor within the framework of the concept of accountability spawns inspiration in expanding accountability. The metaphor of trust is reduced to the accountability trilogy. That is, that the activities of political organizations are not only oriented to the dimensions of human relationships with humans, but also the dimensions of human relationships with God and nature.

\section{Accountability of the Dimensions of Human Relations with God}

\section{God as the Supreme Principal}

Research subjects have the same understanding. They perceive that morale provides an important role for board members in carrying out its functions as representatives of the people and party leaders. The Regional Leadership Council (DPD) of a political party in carrying out its activities is conducted based on the values in the $\mathrm{AD} /$ ART:

"On the basis of responsibility before God Almighty who has decreased the mandate to mankind and to uphold the good and prevent failure, so summarize all the enchantment, taste, inventiveness, and initiative to set foot to realize the noble values of the Divine mandate of the Most Holy (AD/ART Party)."

Based on that thought, there is one interesting expression explicitly expressed by AF:

"Indeed the council is shy, if not optimal".

Statement in writing in the speech of Regional Colloquy (Musda) Report of DPD party is as follows:

"... hope that this Musda III can result in the election of the best trustworthy cadres in carrying out the party's program, capable of carrying out partying, accountable and transparent to achieve political victory."

"..., but at the same time he is able to account for what he does to other and to his Lord."

It can be concluded from the subject of research on the concept of accountability in the dimensions of human relations with God, there are two forms of accountability in the Regional Leadership Council of political parties: spiritual accountability and moral accountability. Spiritual accountability, accountability for spiritual values and not value-free in carrying out daily activities within the political party organization community, such as the value of faith, devotion, and honesty.

Conversely, moral accountability focuses research subjects on moral responsibility to carry out activities that are the duties and responsibilities of a political party. It conducts activities based on existing laws and rules and has principles work well. For example, the delivery of financial statements at the end of the period to the government and in accordance with the provisions of the government.

\section{Accountability of the Dimensions of Human Relationships with Human Beings}

As a khalifah on Earth, amanah (trust) can be used as a basis in various aspects of life in relation to the problem of duties and responsibilities. This is explained in the Hadith, "If one speaks in a negotiation, when he has turned, it is amanah (trust) (H.R. Abu Dawud and Tirmidzi). Thus, words are trusts that must be spoken or issued with a responsibility. For example, when the Regent gives his mandate in front of the DPRD, then all his remarks are noticed by the representatives of the people because it contains the value of trust to be accountable.

The implementation of accountability to human beings is manifested in the form of respect for the rights and the implementation of obligations, as well as a form of love for humans to judge performance towards others, honesty and justice in the interests of personal and community. Thus, God commands humans to do this:

"Allah hath commanded you to deliver a mandate to those who are entitled to receive it, and if establishing the law among men so that you may judge equitably (QS An-Nisa [4]: 58)."

By this conception, accountability among human beings has two purposes: (1) to create social harmony leading to justice and (2) to maintain harmony and justice bringing the welfare of the wider community. It can be used as the basis of the guidelines of political party management.

\section{Stakeholders (Society) as Principals}

In agency theory, the Party Leader (DPD) is an agent of constituents (called principal) who fights for the aspirations and interests of the wider community through its political position. DPD parties as agents of political organizations are held accountable in the form of reports, explanations, directives, or reprimands. The activities of political parties are required to be accountable to five related groups: (1) Cadre and party members; (2) donors; (3) government; (4) KPU; and (5) constituents/communities.

The phrase of the chairman of a political party as Musda "Keeps Steps Together, Enforce the Message, 
Achieve Victory. The statement derives the following understanding: "Matching the Joint move", showing the existence of togetherness among human beings, mutual help happening, and putting together (altruistic) values in advancing the party. This "Confirming the Statement" statement reinforces the notion that human beings with the predicate of the party's political party bear the mandate or party task that must be carried out with a sense of responsibility. While the statement "Achieving Victory" is the responsibility of an organization to gain victory as one indicator of management successful organization.

The form of accountability of financial management of DPD party organization is the submission of financial statements related to monthly activities to party officials (DPD, DPC, and DPrt) as well as party members at the time of Regional colloquy of DPD. Requirements to propose as chair of the DPD should have a good religious understanding in family life.

\section{Accountability of the Dimensions of Human Relations with Nature}

\section{Nature as Principal}

The universe and humans are God's creatures and both are subservient and obedient to Him. Humans could not escape from the various influences of nature around them. Otherwise, humans can also affect the nature around them. The involvement of party DPD in the effort to manage and maintain the universe can be seen from the concerns set forth in the principle of the party, which is based on religious-based morality that brings grace to all of nature. The principle is embodied in the DPD Work Program, in charge of the Infrastructure and Environment Agency, which are reforestation, utilization of waste as organic fertilizer, and DPD formed a team of volunteers handling natural disasters.

The real form of concern DPD to the natural environment can also be seen from the office. The environment office is always aware with cleanliness and leafy plants in the yard office. The cleanliness and beauty of the office will create beauty that can create a sense of calm and coolness in the members and the party management and also create a good working atmosphere. By planting trees, there is a balance in the environment (ecosystem). Here, humans need oxygen from trees, whereas trees need carbon dioxide from humans. In addition, trees store water during rainy season to be used in the dry season. In the dry season, humans do not have water problems.

It can be inferred from the discussion of the research subjects above, the DPD in its activities has a concern of the natural environment (life), open awareness, and knowledge for party members and managers to maintain nature and contribute to save the natural environment.

\section{CONCLUSION}

The demand of accountability is a must for a political party to perform its role as an agent in the election process of the regional head. Accountability is widely understood, not only oriented to the dimensions of among human's relationships, but also the dimensions of human's relationship with Allah and nature. This is the meaning of accountability towards Allah, which reflects the spiritual and moral aspects of the individual in carrying out activities within a political party organization. The meaning of accountability to human beings is to create social harmony which brings justice and welfare of society. The meaning of accountability to nature is to have awareness and knowledge for party officials to preserve nature and not to contribute to the destruction of the natural environment.

\section{REFERENCES}

[1] Swift, $\mathrm{T}$ "Trust, reputation, and corporate accountability to stokeholders. Business Ethics: A European Review 10 (1) : 16-26” 2001.

[2] Raba, M., "Akuntabilitas, Konsep dan Implementasi" UMM Press, 2006.

[3] Jensen and Meckling, " Theory of the Firm: Managerial Behaviour, Agency Cost and Owenership Structur". Journal of Financial Economics, October, Vol. 3, No. 4, pp. 305-360. 1976.

[4] Gray, R. Owen, D. L. and Maunders, K. “ Corporate Social Reporting: Accounting and Accountability. Hemel Hempstead, Herts, Prentice-Hall International, 1987.

[5] Power, "Auditing and, environmental Expertise: Between protest and proffesionalisme". Accounting, Auditing, and Accountability 4 (3): 30-42, 1991.

[6] Sinclair, "The Chameleon of accountability: Forms and discourses". Accounting Organizations and Society 20 (2//3): 219-237, 1995.

[7] Salleh and Iqbal, " Accountabillity, The Endless Prophecy. The Asian and Pacific Development Centre. Malaysia, 1995.

[8] Triyuwono, I. Akuntansi Syari'ah, Perspektif, Metodologi, dan Teori. PT. Raja Grafindo Persada, Jakarta, 2006.

[9] Kholmi, M. “ Akuntabilitas dan Pembentukan Perilaku Amanah dalam Masyarakat Islam", Jurnal Salam Vol 5, No. 1, ISSN 1410-4512, Hal: 63-72., 2012.

[10] Kholmi, M., et al. "Phenomenology Study : Accountability of a Political Party in The Context of Local Election. Procedia - Social and Behavioral Sciences. 211 (2015) 731 - 737. 2015.

[11] Kholmi,M.," Understanding Post-election Accountability : View of Politic Party Board, International conference on Religion, Micro Finance and Community Empowerment (ICOMFIN), departement of Islamic Economics and Banking, UMY 19-21 Juli 2017.

[12] Moleong, “Metodologi Penelitian Kualitatif. PT Remaja Rosdakarya, Bandung, 2008. 